\section{Controlling Bitter Pit in 'Honeycrisp' Apples}

\author{
D.A. Rosenberger ${ }^{1}$,
}

\author{
J.R. Schupp ${ }^{2}$, S.A. Hoying ${ }^{3}$, \\ L. Cheng ${ }^{4}$, and C.B. Watkins ${ }^{4}$
}

ADDITIONAL INDEX wORDs. boron, calcium chloride, harpin protein, trifloxystrobin

Summary. Control of bitter pit in 'Honeycrisp' apples (Malus $\times$ domestica) from trees treated during the growing season with foliar sprays of trifloxystrobin fungicide and calcium was evaluated in four replicated trials over 2 years. All trials were in commercial orchards of 'Honeycrisp' trees that were 3 to 6 years old. The effectiveness of combining boron with foliar applications of calcium chloride $\left(\mathrm{CaCl}_{2}\right)$ was evaluated in two trials, and effectiveness of harpin protein, used either alone or in alternating sprays with $\mathrm{CaCl}_{2}$ was assessed in one trial. Trifloxystrobin applied twice during the $\mathbf{3 0}$ days before harvest reduced bitter pit incidence at harvest in one of the four trials, but the reduction was transitory, no longer being evident when fruit were re-evaluated after $\mathbf{6 3}$ days of cold storage. Harpin protein did not affect disorder incidence. Calcium sprays failed to control bitter pit in treatments where the

This work was funded in part by the New York Apple Research and Development Program; by Smith Lever funds from the Cooperative State Research, Education, and Extension Service, U.S. Department of Agriculture (USDA-CSREES); by USDA-CSREES funding provided to the Cornell University Agricultural Experiment Station for support of Multi-State Research Project NE-1018; and by grants from United Agri Products and Eden Bioscience. The authors thank Fritz Meyer, Cathy Ahlers, Keri VanCamp, Jackie Nock, Jay Osborne, Richard Christiana, and Albert Woelfersheim for technical assistance. We also thank the cooperating growers for contributing fruit for postharvest experiments and allowing experiments to be conducted in their plantings.

${ }^{1}$ Department of Plant Pathology, Hudson Valley Lab, New York State Agricultural Experiment Station, Highland, NY 12528; to whom reprint requests should be addressed. E-mail address: dar22@cornell.edu

${ }^{2}$ Department of Horticultural Sciences, Hudson Valley Lab, New York State Agricultural Experiment Station, Highland, NY 12528.

${ }^{3}$ Cornell Cooperative Extension, Lake Ontario Fruit Team, Newark, NY 14568.

${ }^{4}$ Department of Horticulture, Cornell University, Ithaca, NY 14853. total elemental calcium applied was less than $2.7 \mathrm{lb} /$ acre $\left(3.03 \mathrm{~kg} \cdot \mathrm{ha}^{-1}\right)$ per year for tree canopies that were sprayed to drip using $100 \mathrm{gal} / \mathrm{acre}$ $\left(935.4 \mathrm{~L} \cdot \mathrm{ha}^{-1}\right)$ of spray solution. In the two trials where some treatments involved application of at least 2.9 lb/acre $\left(3.25 \mathrm{~kg} \cdot \mathrm{ha}^{-1}\right)$ of elemental calcium per season, the incidence of fruit with bitter pit at harvest was reduced by $76 \%$ to $90 \%$. Effectiveness of calcium sprays for bitter pit control was not enhanced by superimposing trifloxystrobin, boron, or harpin protein treatments. Flesh firmness at harvest was lower in calcium-treated than in non-treated fruit, and fruit maturity was more advanced on trees receiving boron sprays than on trees receiving no boron. In one trial, where the first calcium application was made approximately 2 weeks after petal fall and 4 days prior to a fruit thinning spray, crop load of trees that received calcium sprays, measured as number of fruit per $\mathrm{cm}^{2}$ trunk cross-sectional area, was $38 \%$ greater than on trees that received no calcium sprays. $\mathrm{CaCl}_{2}$ provided better control of bitter pit in 'Honeycrisp' than any of the other materials tested.

$\mathrm{H}$ oneycrisp' is a relatively new apple cultivar that has a unique crisp juicy texture found in no other commercially available apple cultivar (Tong et al., 1999). The texture of 'Honeycrisp' has generated considerable interest among apple growers and consumers, and the cultivar is being planted throughout northern fruit producing regions in the United States. 'Honeycrisp' has excellent long-term storage characteristics. Apples held in regular air storage for 9 months still retained more crispness than most apples available in retail stores in May and June (Luby and Bedford, 1992).

In many young plantings, however, more than $50 \%$ of 'Honeycrisp' fruit develop bitter pit prior to harvest or during storage (Rosenberger et al., 2001 ). Bitter pit is common in young, lightly cropped trees of other apple cultivars, but in some 'Honeycrisp' plantings bitter pit is still causing significant losses after 4 or 5 years of regular cropping. Further expansion of 'Honeycrisp' plantings will be feasible only if growers can minimize losses to bitter pit.
Bitter pit is a physiological disorder associated with low calcium content in fruit. It is aggravated by excessive tree vigor and fruit size, low soil pH, boron deficiency, and environmental stress such as drought (Faust and Shear, 1968; Ferguson and Watkins, 1989). In other cultivars prone to this disorder, bitter pit can be reduced by applying calcium in foliar sprays during summer. However, effectiveness of spray regimes for controlling bitter pit has been highly variable and the sprays can be phytotoxic to apple foliage, especially when calcium is applied at high concentrations, high temperatures, or in combination with other pesticides (Ferguson and Watkins, 1989).

Several new chemistries that reportedly affect plant physiology and stress responses were recently registered for application to apples. Strobilurin fungicides affect many different aspects of plant metabolism, some of which contribute to increased "greening" and productivity of treated crops (Bartlett et al., 2002; Ypema and Gold, 1999). Kresoxim-methyl has been shown to cause a decrease in the level of 1-aminocyclopropane-1carboxylic acid (ACC), ACC synthase activity, and ethylene production, and it may thereby slow chlorophyll degradation and delay senescence (Ypema and Gold, 1999). Another strobilurin fungicide, trifloxystrobin, reduced bitter pit incidence on apples in 2 years of trials at the Novartis Northeast Research Station in Hudson, N.Y. (M.A. Pastor-Corrales, personal communication). In those trials, trifloxystrobin applied in eight cover sprays in 1998 reduced the incidence of bitter pit in 'Idared,' 'Stayman,' and 'Delicious' by $91 \%, 95 \%$, and $75 \%$, respectively. In 1999, two applications of trifloxystrobin during August reduced bitter pit incidence on 'RedCort' fruit from $29 \%$ in control plots to $5 \%$ in treated plots.

Harpin protein induces systemic acquired resistance in plants (Dong et al., 1999). The harpin protein product label claims that this product can also enhance growth, fruit development and nutrient uptake in a wide range of plant species.

The objective of our experiments was to evaluate the effectiveness of foliar calcium sprays for controlling bitter pit on 'Honeycrisp' apples when calcium sprays are applied alone or in combination with foliar boron, 
trifloxystrobin, and harpin protein treatments.

\section{Materials and methods}

Field trials were conducted for two consecutive years in 'Honeycrisp' orchards in the Hudson Valley (southeastern New York state) and for 1 year in a western New York 'Honeycrisp' orchard near Lyndonville, Niagara County, N.Y. In the Hudson Valley, treatments in 2000 were applied to sixth-leaf trees on 'Malling 26' rootstock (Milton, Ulster Co., N.Y.) and to fifth-leaf trees on 'Malling 9' rootstock (Gardiner, Ulster Co., N.Y.). The same Milton orchard was used for the 2001 field trial. In 2001, treatments were also applied to third-leaf trees on 'Malling 9' rootstock near Lyndonville. In all trials, growers applied routine fungicide, insecticide, and nutritional programs without any strobilurin fungicide sprays or foliar calcium sprays.

A randomized block design was used for all of the trials. In the Hudson Valley, trees were placed into replicates based on blossom density assessed when trees were slightly past king bloom. Trees with similar blossom densities were used for comparisons within replicates because fruit load is known to influence susceptibility to bitter pit. Single-tree plots were used for experiments at Gardiner and Milton. Five-tree plots were used at Lyndonville. Treatments were replicated five times in all locations.

Treatments at Lyndonville were applied with a Solo 425 backpack sprayer (Solo Inc., Newport News, Va.) whereas a high-pressure pump and handgun were used to spray trees at Gardiner and Milton. In all locations, spray volume was determined by spraying trees until the spray solution began to drip from leaves. In all except the
Gardiner orchard, fruit were harvested and evaluated to determine how field treatments affected fruit maturity, fruit mineral content and the incidence of externally-visible bitter pit at harvest and after cold storage. In the Gardiner trial, the only data collected was incidence of bitter pit at harvest.

Gardiner and Milton trials, 2000. A factorial design was used to evaluate trifloxystrobin-calcium interactions. Treatments included a control (no summer sprays of trifloxystrobin or calcium), trifloxystrobin fungicide (Flint 50WDG, Novartis, Inc., Greensboro, N.C. ) at $1 \mathrm{oz} / 100 \mathrm{gal}(75$ $\left.\mathrm{mg} \cdot \mathrm{L}^{-1}\right)$ of formulated product applied on 4 and 15 Aug., calcium applied on 3 and 17 July and 4 and 15 Aug., and a combination of the trifloxystrobin and calcium treatments. Calcium sprays consisted of NorCOP Calcium Mannitol Solution (Notrace, Ltd., Greeley, Colo.) applied at lqt/100 gal $\left(2.5 \mathrm{~mL} \cdot \mathrm{L}^{-1}\right)$, a rate that provided $0.29 \mathrm{lb} / 100 \mathrm{gal}\left(347 \mathrm{mg} \cdot \mathrm{L}^{-1}\right)$ of actual calcium in each application.

Harvest samples consisting of 50 randomly selected fruit per tree were collected on 5 Sept. 2000. At the Milton orchard, the fruit remaining on the tree after the harvest samples had been removed were counted to determine total crop load. Trunk diameters were measured at 12 inches $(30.5 \mathrm{~cm})$ above the soil line during late Oct. 2000 to allow calculation of fruit $/ \mathrm{cm}^{2}$ of trunk cross-sectional area (TCSA). The 50-fruit harvest samples were used to assess incidence and severity of externally-visible bitter pit immediately after harvest and again after $85 \mathrm{~d}$ cold storage at $34.5^{\circ} \mathrm{F}\left(1.39^{\circ} \mathrm{C}\right)$.

An additional 20 -fruit subsample of mid-sized fruit was harvested from each tree for determination of fruit firmness and fruit mineral content. A
Model EPT-1 Pressure Tester (Lake City Technical Products, Kelowna, B.C., Canada) fitted with an 11.1mm-diameter probe was used to measure fruit firmness on opposite faces of each fruit. Tissue samples were collected from the same 20 fruit for mineral analyses. Tissue was collected by cutting a 0.25 inch $(6.4 \mathrm{~mm})$-thick equatorial slice through the core of the apple, then removing two 0.31inch- $(8 \mathrm{~mm})$ diameter plugs from just beneath the skin on opposite sides of the slice and pooling the samples for all of the apples from the same tree (Turner et al., 1977). After drying, fruit tissues were wet-ashed and mineral concentrations were analyzed by using an inductively coupled argon plasma (ICP) atomic emission spectrometer in the ICP Nutrient Analysis Lab of the Department of Horticulture at Cornell University, Ithaca (Greweling, 1976).

Milton 2001. Trees in test plots were treated during summer with CorClear Calcium Chloride (97\% $\mathrm{CaCl}_{2}$; Sego International, Portland, Ore.) either alone or in combination with other products that might affect bitter pit development (Table 1). In addition to foliar $\mathrm{CaCl}_{2}$ sprays, other products tested as foliar sprays included trifloxystrobin fungicide, sodium borate (Solubor, $20.5 \%$ boron from sodium borate; U.S. Borax, Valencia, Calif.) and harpin protein (Messenger, 3\% harpin protein; Eden Bioscience, Bothell, Wash.). A factorial design was used to compare five treatments (control, trifloxystrobin, sodium borate, harpin protein, and a trifloxystrobin+sodium borate+harpin protein combination) applied either alone or in conjunction with the $\mathrm{CaCl}_{2}$ spray schedule (Table 1 ). $\mathrm{CaCl}_{2}$ was applied six times at bi-weekly inter-

Table 1. Treatments and dates they were applied to 'Honeycrisp' apple trees at the orchard in Milton, N.Y., in 2001.

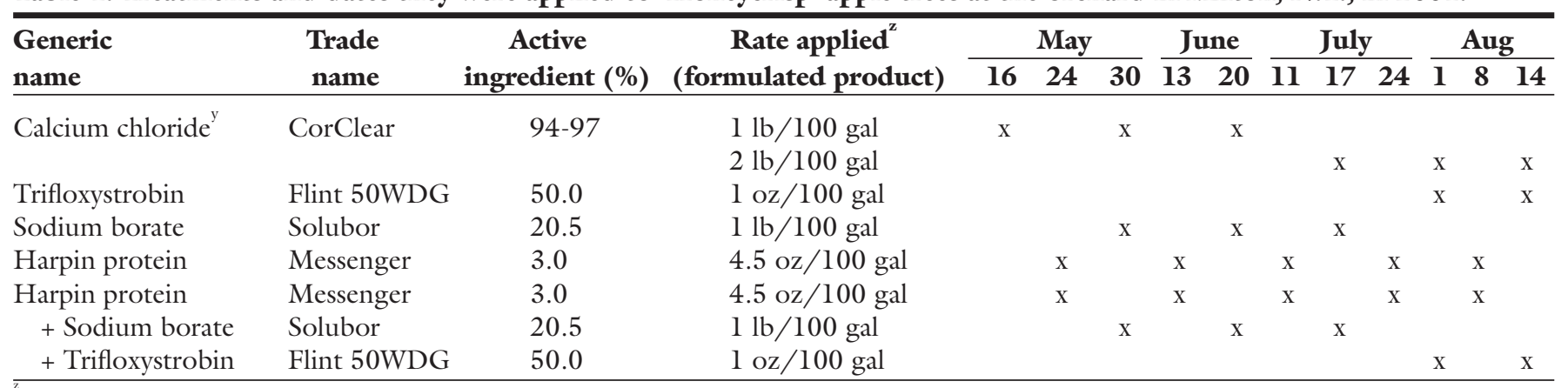

$1 \mathrm{lb} / 100 \mathrm{gal}=1.2 \mathrm{~g} \cdot \mathrm{L}^{-1} ; \mathrm{l} \mathrm{qt} / \mathrm{l} 00 \mathrm{gal}=2.5 \mathrm{~mL} \cdot \mathrm{L}^{-1} ; \mathrm{l} \mathrm{oz} / \mathrm{l} 00 \mathrm{gal}=75 \mathrm{mg} \cdot \mathrm{L}^{-1}$

'The calcium chloride treatment was superimposed over half of all the plots in this trial using a factorial design that allowed evaluation of interactions between calcium chloride and other treatments. Calcium chloride sprays were tank mixed with other products applied on the same dates. 
vals. Harpin protein was applied five times on alternate weeks to avoid any possibility that harpin protein would be inactivated by other products in a tank mix. Sodium borate was applied three times to the replicated plots. Trifloxystrobin was applied twice in August, about 28 and $14 \mathrm{~d}$ before harvest.

Trees in the test orchard reached petal fall on 12 May. The grower's spray program on this farm included sodium borate applied at $2.4 \mathrm{lb} /$ acre $\left(2.69 \mathrm{~kg} \cdot \mathrm{ha}^{-1}\right)$ on 2,22 , and 29 May and Epsom salts at $21 \mathrm{lb} /$ acre $(23.5$ $\left.\mathrm{kg} \cdot \mathrm{ha}^{-1}\right)$ on $29 \mathrm{May}, 29 \mathrm{lb} /$ acre $(32.5$ $\left.\mathrm{kg} \cdot \mathrm{ha}^{-1}\right)$ on 6 and 26 June, and 14 $\mathrm{lb} /$ acre $\left(15.7 \mathrm{~kg} \cdot \mathrm{ha}^{-1}\right)$ on 15 June and 9 July.

A random sample of 90 fruit was harvested from each tree on 29 Aug., and fruit remaining on the tree after sampling were counted. Mature fruit that dropped to the ground prior to 29 Aug. were also counted. Trunk diameters were measured at 12 inches above the soil line on 30 Oct. to allow calculation of fruit numbers per $\mathrm{cm}^{2}$ TCSA.

Ten fruit were used to assess fruit firmness and starch content immediately after harvest. Starch hydrolysis was assessed on a scale of 1 (no hydrolyzed starch) to 8 (all starch hydrolyzed) using the Cornell generic starch index (Blanpied and Silsby, 1992). Eighty fruit were evaluated for bitter pit. The 80 fruit were then divided into two boxes of 40 fruit each. One box was dipped for $30 \mathrm{~s}$ in a solution contain- ing CorClear Calcium Chloride (94 to $\left.97 \% \mathrm{CaCl}_{2}\right)$ at $2.5 \mathrm{lb} / 100 \mathrm{gal}(3.0$ $\left.\mathrm{g} \cdot \mathrm{L}^{-1}\right)$. All fruit in this experiment were held at $69^{\circ} \mathrm{F}\left(20.6^{\circ} \mathrm{C}\right)$ until 31 Aug. when the $\mathrm{CaCl}_{2}$ postharvest treatments were applied. Fruit were then moved to cold storage at $37^{\circ} \mathrm{F}\left(2.8^{\circ} \mathrm{C}\right)$. Fruit were assessed for incidence of bitter pit after $63 \mathrm{~d}$ of cold storage. At the time of the final rating on $1-2$ Nov., each sample of fruit was weighed to determine mean fruit weight. A 15fruit sub-sample was collected from each of the 100 experimental lots $(20$ field treatments $\times 5$ replications $\times 2$ $\mathrm{CaCl}_{2}$ postharvest treatments) after fruit were removed from storage, and the sub-samples were analyzed for fruit mineral content at the Cornell ICP Nutrient Analysis Laboratory.

LyNDONVILle, 2001. Six different calcium formulations and trifloxystrobin fungicide were compared using the rates suggested by the product manufacturers (Table 2). Calcium treatments were applied to trees on 28 June, 14 and 20 July, and 3, 17, and 23 Aug. Trifloxystrobin was applied only on 17 and 23 Aug. All calcium treatments were applied with the adjuvant LI-700 (Loveland Industries, Greeley, Colo.) used at a rate of $16 \mathrm{fl}$ $\mathrm{oz} / 100 \mathrm{gal}\left(1.25 \mathrm{~mL} \cdot \mathrm{L}^{-1}\right)$. Control trees were unsprayed except for the grower-applied standard pesticides. Mature fruit were harvested on 15 Sept. and were stored at $33^{\circ} \mathrm{F}\left(0.6^{\circ} \mathrm{C}\right)$ for $90 \mathrm{~d}$. Fruit firmness and mineral content were determined as described previously.

\section{Results}

Year 2000 trials. Calcium treatments did not provide significant reductions in bitter pit in either of the trials conducted during the 2000 growing season. At Milton, the replicate involving trees with the heaviest crop averaged 6.83 fruit $/ \mathrm{cm}^{2}$ TCSA, and fruit from this replicate had relatively little bitter pit due to their smaller fruit size. With that replicate omitted in a subsequent analysis, the mean incidence of bitter pit at harvest was $47 \%$ lower for fruit treated with trifloxystrobin than for fruit receiving no trifloxystrobin (i.e., 11\% vs. 20\% of fruit with bitter pit, Table 3). However, the effect of trifloxystrobin on bitter pit disappeared during cold storage. Treated and non-treated fruit had similar levels of bitter pit ( $21 \%$ vs. $24 \%)$ after $85 \mathrm{~d}$ of cold storage (Table 3 ).

None of the treatments at Milton affected concentrations of calcium in fruit $(P=0.23)$. The calcium sprays used in Milton did not affect fruit firmness either at harvest $(P=0.19)$ or after $85 \mathrm{~d}$ of cold storage $(P=0.52)$.

At Gardiner, trees had a very light crop (mean of only 18.8 fruit per tree) and fruit were therefore evaluated only at harvest. Trees treated with trifloxystrobin had $27 \%$ less fruit with bitter pit than trees not receiving trifloxystrobin, but this difference was not significant $(P=0.23)$.

Milton, 2001. $\mathrm{CaCl}_{2}$ applied six times during summer reduced the incidence of bitter pit by 76 and $47 \%$

Table 2. Foliar treatments applied to 'Honeycrisp' apple trees at Lyndonville, N.Y., and effects of treatments on incidence of fruit with externally visible bitter pit as determined after cold storage.

\begin{tabular}{|c|c|c|c|c|c|}
\hline Treatment & Manufacturer $^{\mathrm{z}}$ & $\begin{array}{l}\text { \% Elemental } \\
\text { calcium } \\
\text { in the } \\
\text { formulation }\end{array}$ & $\begin{array}{l}\text { Application rate } \\
\text { (formulated } \\
\text { product/100 } \\
\text { gal of spray) }\end{array}$ & $\begin{array}{c}\text { Total amount } \\
\text { of elemental } \\
\text { calcium applied } \\
\text { (lb/acre) }\end{array}$ & $\begin{array}{c}\text { Fruit with } \\
\text { bitter pit } \\
\text { after cold } \\
\text { storage }(\%)^{x}\end{array}$ \\
\hline Control & --- & --- & --- & --- & $27 c^{w}$ \\
\hline \multicolumn{6}{|l|}{ DowFlake Process Grade } \\
\hline Calcium Chloride & Dow Chemical & 28 & $3 \mathrm{lb}+6 \mathrm{lb}^{\mathrm{v}}$ & 6.8 & $3 a$ \\
\hline Stop It Liquid Calcium Chloride & Pace International & 12 & $1 \mathrm{qt}+2 \mathrm{qt}^{\mathrm{v}}$ & 2.9 & $4 \mathrm{a}$ \\
\hline Nortrace $10 \%$ Calcium & UAP-Nortrace & 10 & $2 \mathrm{qt}$ & 3.5 & $6 a$ \\
\hline Nortrace Norplex 6 & UAP-Nortrace & 6 & $2 \mathrm{qt}$ & 1.8 & $18 \mathrm{ab}$ \\
\hline Nortrace Norplex 6 plus Boron & UAP-Nortrace & 6 & $2 \mathrm{qt}$ & 1.8 & $16 \mathrm{ab}$ \\
\hline Trifloxystrobin & Novartis & 0 & $3 \mathrm{oz}$ & --- & $19 \mathrm{bc}$ \\
\hline
\end{tabular}

${ }^{2}$ Dow Chemical Co., Midland, Mich.; Cerexagri, King of Prussia, Pa.; Pace International LLC, Kirkland, Wash.; UAP-Nortrace Ltd., Ozark, Ala.; Novartis, Greensboro, N.C.

y $\left(1 \mathrm{lb} / 100 \mathrm{gal}=1.2 \mathrm{~g} \cdot \mathrm{L}^{-1} ; 1 \mathrm{qt} / 100 \mathrm{gal}=2.5 \mathrm{~mL} \cdot \mathrm{L}^{-1} ; \mathrm{l} \mathrm{oz} / 100 \mathrm{gal}=75 \mathrm{mg} \cdot \mathrm{L}^{-1} ; \mathrm{l} \mathrm{lb} / \mathrm{acre}=1.2 \mathrm{~kg} \cdot \mathrm{ha}{ }^{-1}\right)$.

${ }^{x}$ Bitter pit was rated after $90 \mathrm{~d}$ of cold storage followed by a 7 -d shelf-life test at $68{ }^{\circ} \mathrm{F}\left(20.0{ }^{\circ} \mathrm{C}\right)$.

"Means followed by the same small letter are not significantly different as determined using Fishers protected least significant difference test $(P=0.05)$.

vFour applications at the first rate followed by two applications at the second rate. 
Table 3. Incidence of bitter pit on 'Honeycrisp' apple fruit harvested in 2001 from the orchard in Milton, N.Y., as affected by application of trifloxystrobin and calcium chloride foliar sprays during summer.

\begin{tabular}{|c|c|c|c|c|c|c|}
\hline \multirow[b]{3}{*}{$\begin{array}{l}\text { Trifloxystrobin } \\
\text { treatment }^{z}\end{array}$} & \multicolumn{3}{|c|}{ Fruit with bitter pit at harvest (\%) } & \multicolumn{3}{|c|}{ Fruit with bitter pit after 85 d cold storage (\%) } \\
\hline & \multicolumn{2}{|c|}{ Calcium chloride $\left(\mathrm{CaCl}_{2}\right)$} & \multirow{2}{*}{$\begin{array}{l}\text { Grand means } \\
\text { for effects of } \\
\text { trifloxystrobin }\end{array}$} & \multicolumn{2}{|c|}{ Calcium chloride $\left(\mathrm{CaCl}_{2}\right)$} & \multirow{2}{*}{$\begin{array}{l}\text { Grand means } \\
\text { for effects of } \\
\text { trifloxystrobin }\end{array}$} \\
\hline & None & $\begin{array}{c}\text { Four } \\
\text { applications }^{\mathrm{z}}\end{array}$ & & None & $\begin{array}{c}\text { Four } \\
\text { applications }^{\mathrm{z}}\end{array}$ & \\
\hline None & 12 & 27 & 20 & 25 & 23 & $24^{x}$ \\
\hline Two applications & 9 & 13 & $11^{* y}$ & 19 & 22 & 21 \\
\hline Grand means: & & & & & & \\
\hline
\end{tabular}

Table 4. Fruit maturity ratings and incidence of bitter pit in 'Honeycrisp' apple fruit harvested in 2001 from the orchard in Milton, N.Y., as affected by foliar treatments of calcium chloride $\left(\mathrm{CaCl}_{2}\right)$, trifloxystrobin, sodium borate, and harpin protein applied in various combinations.

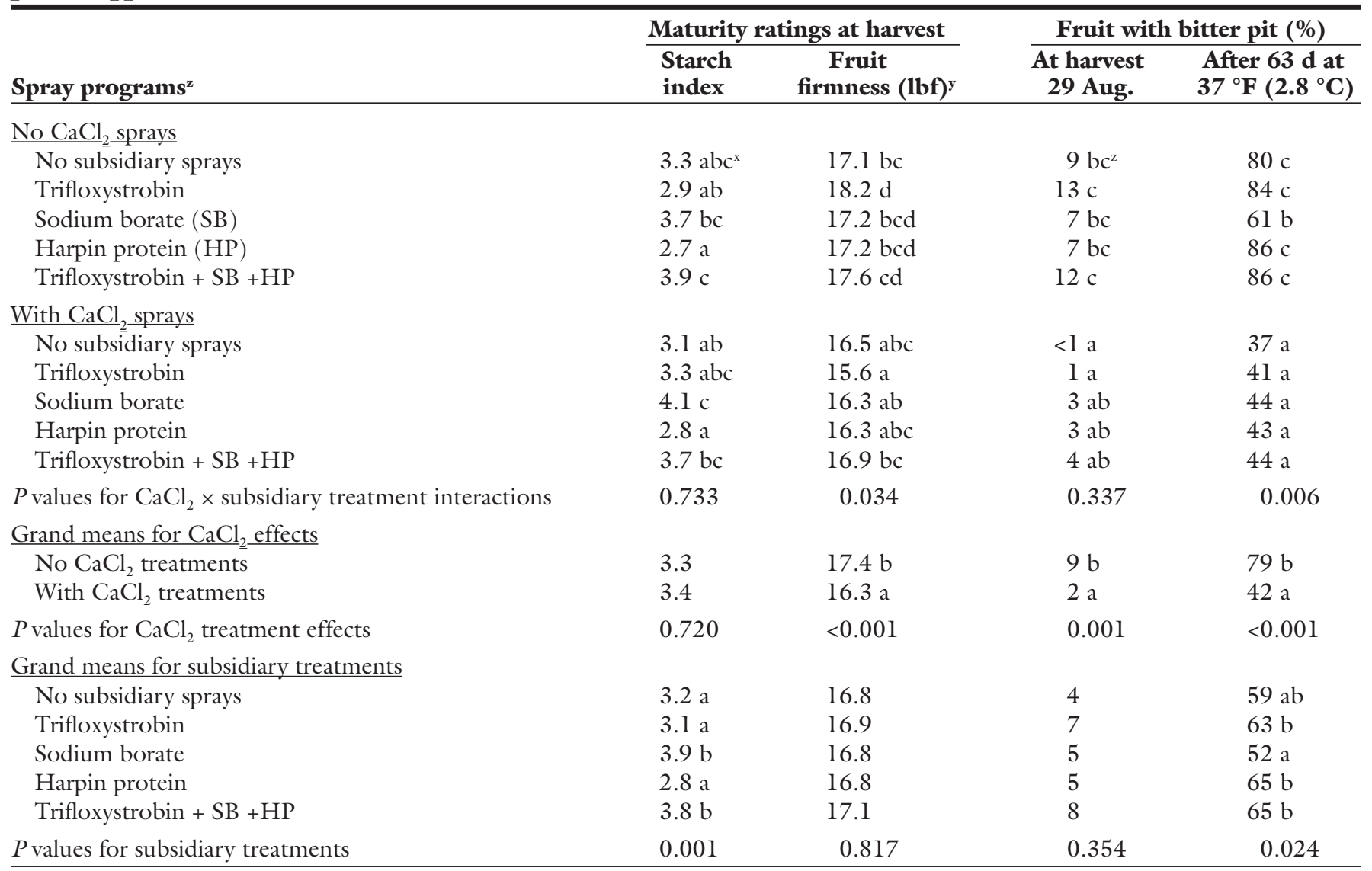

${ }^{2}$ See Table 1 for details of rates and spray application dates.

$\mathrm{y} l \mathrm{lbf}=4.45 \mathrm{~N}$

${ }^{x}$ Letter separations within columns for simple means or for grand means were determined using Fisher's protected least significant difference test $(P=0.05)$ applied to the results of two-way analyses wherein trees with or without calcium foliar sprays were subjected to five subsidiary treatments.

for ratings at harvest and after $63 \mathrm{~d}$ of storage, respectively. The mean incidence of fruit with bitter pit at harvest was $2.2 \%$ for trees sprayed with $\mathrm{CaCl}_{2}$ compared with $9.2 \%$ for trees receiving no $\mathrm{CaCl}_{2}$ sprays (Table 4 ). After storage, bitter pit was evident on $41.8 \%$ of fruit from trees sprayed with $\mathrm{CaCl}_{2}$ compared with $79.4 \%$ for trees with no $\mathrm{CaCl}_{2}$ sprays. Postharvest treatment with $\mathrm{CaCl}_{2}$ did not affect development of bitter pit during storage (data not presented). Treatments involving trifloxystrobin, sodium borate, and harpin protein did not affect the incidence of bitter pit (Table 4).

Fruit from trees sprayed with $\mathrm{CaCl}_{2}$ had less bitter pit on both evaluation dates. However, after $63 \mathrm{~d}$ of storage there was an interaction be- tween the $\mathrm{CaCl}_{2}$ and the supplemental treatments, primarily because sodium borate suppressed bitter pit slightly in trees that did not receive $\mathrm{CaCl}_{2}$ sprays but had no effect on bitter pit in trees sprayed with $\mathrm{CaCl}_{2}$ (Table 4). Thus, the effects of $\mathrm{CaCl}_{2}$ and sodium borate were not additive.

Fruit from trees sprayed with $\mathrm{CaCl}_{2}$ were softer at harvest than fruit 
Table 5. Productivity, premature drop, fruit size and shoot growth from 'Honeycrisp' apple trees in 2001 in the orchard in Milton, N.Y., as affected by foliar treatments of calcium chloride $\left(\mathrm{CaCl}_{2}\right)$, trifloxystrobin, sodium borate, and harpin protein applied in various combinations.

\begin{tabular}{|c|c|c|c|c|c|}
\hline \multirow[b]{2}{*}{ Spray programs ${ }^{y}$} & \multicolumn{2}{|c|}{$\begin{array}{l}\text { No. of fruit per } \mathrm{cm}^{2} \\
\text { trunk cross-sectional area }\end{array}$} & \multirow{2}{*}{$\begin{array}{l}\text { Premature drop } \\
\text { as a percent } \\
\text { of total crop }\end{array}$} & \multirow{2}{*}{$\begin{array}{c}\text { Mean } \\
\text { fruit } \\
\text { wt (g) }\end{array}$} & \multirow{2}{*}{$\begin{array}{l}\text { Mean } \\
\text { shoot } \\
\text { growth (cm) }\end{array}$} \\
\hline & Total crop & Harvested crop & & & \\
\hline \multicolumn{6}{|l|}{$\underline{\mathrm{No} \mathrm{CaCl}_{2} \text { sprays }}$} \\
\hline No subsidiary sprays & $3.6 a b c^{y}$ & $3.2 \mathrm{abc}$ & $12.5 \mathrm{c}$ & $299 \mathrm{~cd}$ & 32 \\
\hline Trifloxystrobin & $2.1 \mathrm{a}$ & $1.9 \mathrm{a}$ & $7.7 \mathrm{abc}$ & $300 \mathrm{~cd}$ & 27 \\
\hline Sodium borate (SB) & $4.3 \mathrm{bcd}$ & 3.9 cde & $7.9 \mathrm{abc}$ & $294 \mathrm{~cd}$ & 22 \\
\hline Harpin protein $(\mathrm{HP})$ & $3.2 \mathrm{ab}$ & $2.9 \mathrm{abc}$ & $7.9 \mathrm{abc}$ & $313 \mathrm{~d}$ & 30 \\
\hline Trifloxystrobin $+\mathrm{SB}+\mathrm{HP}$ & $2.4 \mathrm{a}$ & $2.2 \mathrm{ab}$ & $9.1 \mathrm{bc}$ & $322 \mathrm{~d}$ & 30 \\
\hline \multicolumn{6}{|l|}{ With $\mathrm{CaCl}_{2}$ sprays } \\
\hline No subsidiary sprays & $6.1 \mathrm{e}$ & $5.7 \mathrm{f}$ & $5.3 \mathrm{ab}$ & $240 \mathrm{a}$ & 27 \\
\hline Trifloxystrobin & $5.8 \mathrm{de}$ & $5.2 \mathrm{ef}$ & $8.8 \mathrm{abc}$ & $256 \mathrm{ab}$ & 27 \\
\hline Sodium borate & $3.9 \mathrm{abcd}$ & 3.6 bcde & $6.5 \mathrm{abc}$ & $275 \mathrm{bc}$ & 27 \\
\hline Harpin protein & $5.4 \mathrm{cde}$ & $4.9 \mathrm{def}$ & $7.6 \mathrm{abc}$ & $256 \mathrm{ab}$ & 29 \\
\hline Trifloxystrobin $+\mathrm{SB}+\mathrm{HP}$ & $3.7 \mathrm{abc}$ & $3.5 \mathrm{abcd}$ & $4.5 \mathrm{a}$ & $269 \mathrm{abc}$ & 29 \\
\hline \multicolumn{6}{|l|}{$P$ values for interaction between } \\
\hline $\mathrm{CaCl}_{2}$ and subsidiary treatments & 0.039 & 0.040 & 0.153 & 0.408 & 0.505 \\
\hline \multicolumn{6}{|l|}{ Grand means for $\mathrm{CaCl}_{2} \underline{\text { treatment }}$} \\
\hline No $\mathrm{CaCl}_{2}$ treatments & $3.1 \mathrm{a}$ & $2.8 \mathrm{a}$ & $9.0 \mathrm{~b}$ & $305 \mathrm{~b}$ & 28 \\
\hline With $\mathrm{CaCl}_{2}$ treatments & $5.0 \mathrm{~b}$ & $4.6 \mathrm{~b}$ & $6.6 \mathrm{a}$ & 259 a & 28 \\
\hline$P$ values for $\mathrm{CaCl}_{2}$ treatment effects & $<0.001$ & $<0.001$ & 0.038 & $<0.001$ & 0.825 \\
\hline \multicolumn{6}{|l|}{ Grand means for subsidiary treatments } \\
\hline No subsidiary treatment & 4.9 & 4.5 & 8.9 & 269 & 30 \\
\hline Trifloxystrobin & 3.9 & 3.6 & 8.3 & 278 & 26 \\
\hline Sodium borate & 4.1 & 3.8 & 7.2 & 284 & 25 \\
\hline Harpin protein & 4.3 & 3.9 & 7.8 & 284 & 30 \\
\hline Trifloxystrobin $+\mathrm{SB}+\mathrm{HP}$ & 3.0 & 2.9 & 6.9 & 296 & 30 \\
\hline$P$ values for subsidiary treatment effects & 0.092 & 0.100 & 0.886 & 0.214 & 0.238 \\
\hline \multicolumn{6}{|l|}{ Block effects } \\
\hline Block I (full bloom, large trees) & $2.3 \mathrm{a}$ & $2.2 \mathrm{a}$ & 6.6 & $331 \mathrm{~d}$ & $31 \mathrm{~cd}$ \\
\hline Block IV (light bloom, large trees) & $3.1 \mathrm{ab}$ & $2.8 \mathrm{ab}$ & 9.1 & $274 \mathrm{~b}$ & $35 \mathrm{~d}$ \\
\hline Block V (light bloom, small trees) & $4.2 \mathrm{~b}$ & $3.9 \mathrm{bc}$ & 8.8 & 247 a & $25 \mathrm{ab}$ \\
\hline Block II (full bloom, medium trees) & $4.4 \mathrm{~b}$ & $4.1 \mathrm{c}$ & 6.5 & $301 \mathrm{c}$ & $28 \mathrm{bc}$ \\
\hline Block III (full bloom, small trees) & $6.1 \mathrm{c}$ & $5.6 \mathrm{~d}$ & 8.1 & $258 \mathrm{ab}$ & $20 \mathrm{a}$ \\
\hline$P$-values for block effects & $<0.001$ & $<0.001$ & 0.427 & $<0.001$ & $<0.001$ \\
\hline
\end{tabular}

${ }^{\mathrm{z}} 1 \mathrm{~cm}^{2}=0.155$ inch $^{2} ; \mathrm{l} \mathrm{g}=0.035 \mathrm{oz} ; \mathrm{l} \mathrm{cm}=0.394$ in.

yee Table 1 for details for rates and spray application dates.

'Letter separations within columns for simple means or for grand means were determined using Fisher's protected least significant difference test $(P=0.05)$ applied to the results of two-way analyses wherein trees with or without calcium foliar sprays were subjected to five subsidiary treatments. Each treatment combination was replicated five times.

from trees that received no $\mathrm{CaCl}_{2}$ (Table 4). $\mathrm{CaCl}_{2}$ did not affect the starch maturity index, but ethylene production by the fruit was not measured. Therefore, it is uncertain if differences in firmness are attributable to advanced maturity of fruit from trees sprayed with $\mathrm{CaCl}_{2}$ as shown for other cultivars in New York (Watkins, 1997). Reduced fruit firmness in $\mathrm{CaCl}_{2}$-treated trees is especially surprising because $\mathrm{CaCl}_{2}$ treatment also resulted in increased fruit set and reduced fruit size (Table $5)$. Trifloxystrobin applied alone produced the firmest fruit whereas trifloxystrobin applied with $\mathrm{CaCl}_{2}$ produced the softest fruit.

The mean fruit calcium content across all trees that received $\mathrm{CaCl}_{2}$ sprays during summer was $18 \mathrm{ppm}$ greater than for fruit from trees that did not receive calcium sprays during summer (Table 6). Where $\mathrm{CaCl}_{2}$ sprays were not applied, fruit sprayed with trifloxystrobin or sodium borate alone had more calcium than control fruit whereas both treatments that included harpin protein had less calcium than control fruit. Where $\mathrm{CaCl}_{2}$ was applied, the highest calcium concentration occurred in fruit sprayed with $\mathrm{CaCl}_{2}$ alone and the lowest occurred where both trifloxystrobin and $\mathrm{CaCl}_{2}$ were applied. Application of $\mathrm{CaCl}_{2}$ also contributed to lowered concentrations of potassium and phosphorus in fruit along with increased concentrations of manganese.

Sodium borate treatments increased fruit boron concentrations (Table 6). When sodium borate was applied in combination with trifloxystrobin and harpin protein, fruit boron concentrations were higher than when sodium borate was applied alone. Treatment with sodium borate, either alone or in combination with trifloxystrobin and harpin protein, resulted in advanced fruit maturity as judged by the starch index (Table 4). However, sodium borate did not affect fruit firmness. Trifloxystrobin-treated fruit had higher boron concentrations than fruit treated with harpin protein alone but 
Table 6. Mineral content of 'Honeycrisp' apple fruit harvested in 2001 from the orchard in Milton, N.Y., as affected by foliar treatments of calcium chloride $\left(\mathrm{CaCl}_{2}\right)$, trifloxystrobin, sodium borate, and harpin protein applied in various combinations.

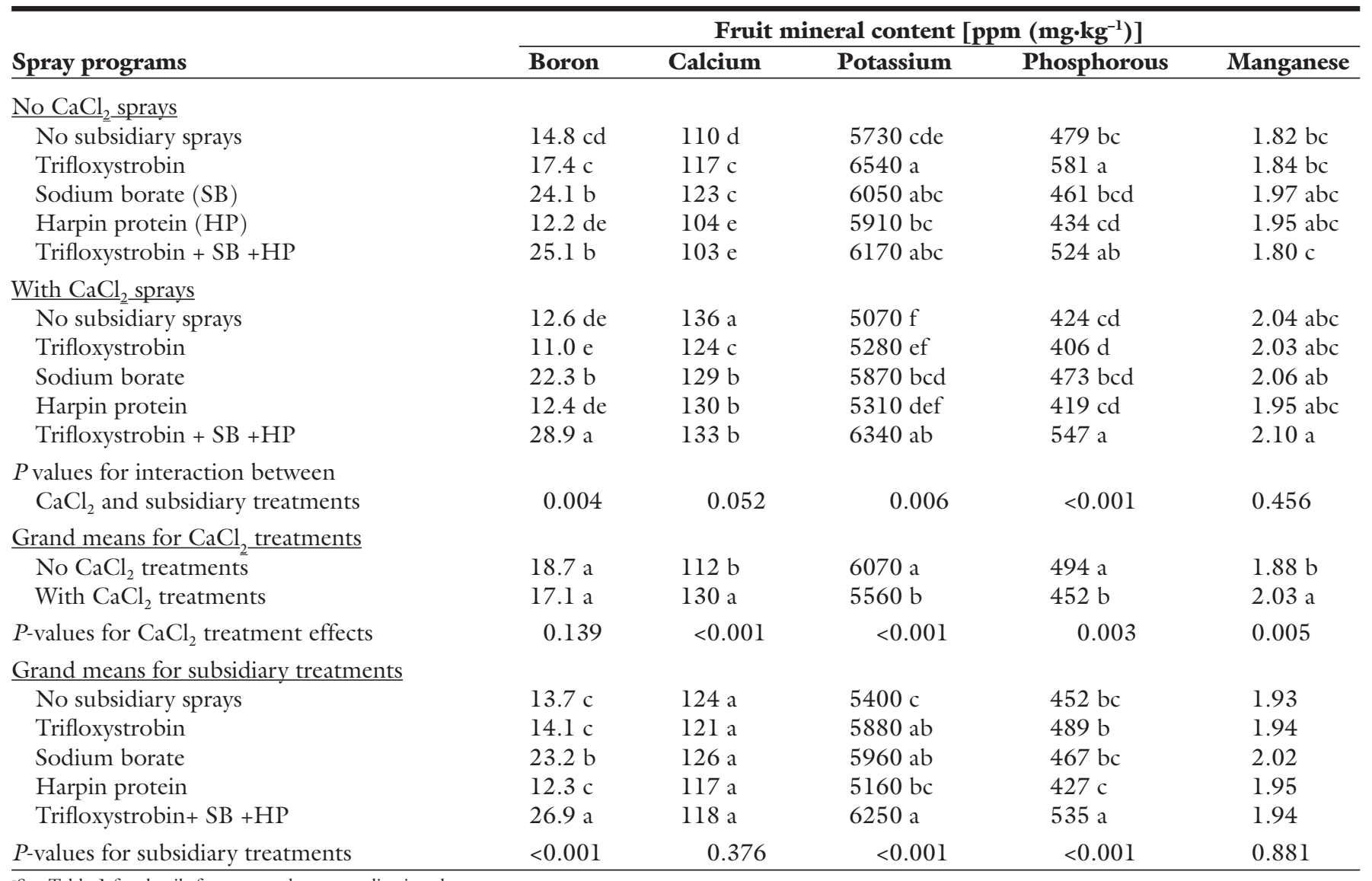

${ }^{\mathrm{z}}$ See Table $\mathrm{l}$ for details for rates and spray application dates.

'Letter separations within columns for simple means or for grand means were determined using Fisher's protected least significant difference test $(P=0.05)$ applied to the results of two-way analyses wherein trees with or without calcium foliar sprays were subjected to five subsidiary treatments. Each treatment combination was replicated five times.

not when summer sprays of $\mathrm{CaCl}_{2}$ were added to the trifloxystrobin and harpin protein treatments (Table 6 ).

Trees treated with $\mathrm{CaCl}_{2}$ had 4.6 harvestable fruit $/ \mathrm{cm}^{2}$ TCSA compared with only 2.8 for trees that did not receive $\mathrm{CaCl}_{2}$ (Table 5). Sodium borate treatment produced the highest crop load among trees not sprayed with $\mathrm{CaCl}_{2}$ and the second lowest crop load among trees that were sprayed with $\mathrm{CaCl}_{2}$.

Differences in bloom density and trunk diameters were used to assign trees to replicates, and therefore replicates differed in crop load, fruit size, and terminal shoot length (Table $5)$. Replicates with the lightest crop generally produced the most shoot growth and the largest fruit. Although the inverse relationship between crop load and shoot growth was observed when replicates were compared, treatments did not affect shoot growth even though trees treated with $\mathrm{CaCl}_{2}$ had a heavier crop load.

Lyndonville, 2001. Control of bitter pit was directly related to the amount of calcium applied during the season regardless of the formulation of calcium used. In four treatments where trees received at least $2.9 \mathrm{lb} /$ acre of elemental calcium, bitter pit was reduced by 79 to $91 \%$ compared with control trees (i.e., bitter pit incidence was 3\% to $6 \%$ in calcium-treated trees compared with $27 \%$ in control trees). Bitter pit was reduced by only 36 to $40 \%$ in two treatments where trees received only $1.8 \mathrm{lb} /$ acre $(2.02$ $\mathrm{kg} \cdot \mathrm{ha}^{-1}$ ) of elemental calcium (Table 2 ). Trifloxystrobin did not control bitter pit in the Lyndonville trial.

In the three trials where fruit mineral content was analyzed, there was a significant linear relationship between mean calcium content in fruit from individual trees and the incidence of bitter pit in fruit from those same trees (Fig. 1). Calcium concentrations in fruit accounted for $35 \%$ to $48 \%$ of the variability in incidence of bitter pit after cold storage. Calcium concentrations in fruit fell within the same range for Lyndonville and Milton 2000, but were somewhat higher for fruit from Milton in 2001.

\section{Discussion}

The experimental design provided a severe test for controlling bitter pit because treatments were applied to young, lightly cropping trees. Also, fruit were harvested at the very earliest stages of acceptable fruit maturity because the random samples had to be harvested before the first color picking was done by the cooperating growers. The fruit used for bitter pit evaluations were randomly selected from throughout the tree canopy and were therefore even more immature than commercially harvested fruit where only highly colored fruit would be removed on the first harvest. Bitter pit is usually more severe on immature than on mature fruit (Ferguson and Watkins, 1989). Cooling of harvested fruit from the 2001 Milton trial was delayed $2 \mathrm{~d}$ while fruit were rated and the postharvest $\mathrm{CaCl}_{2}$ treatment was 


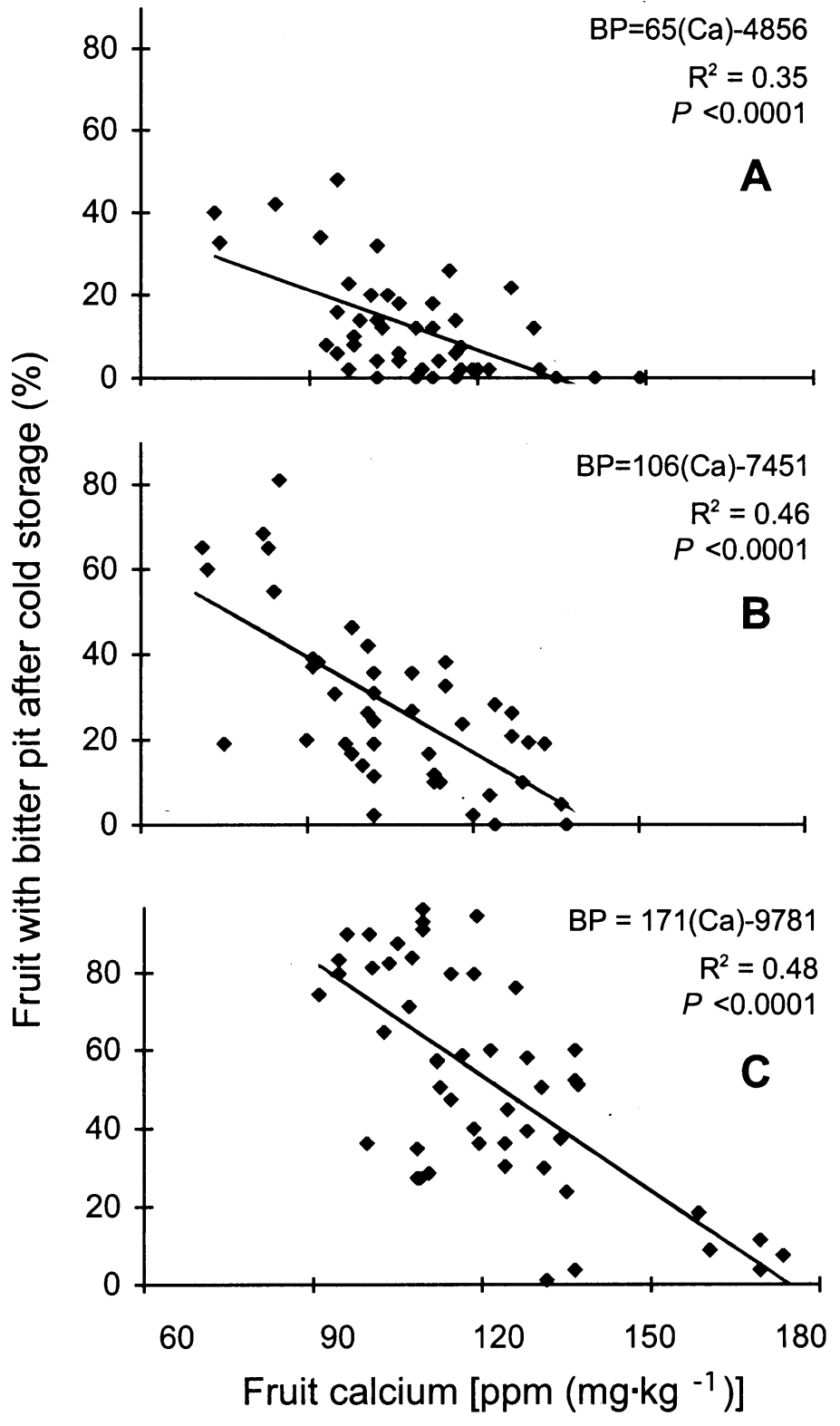

Fig. 1. Linear regressions showing effects of fruit calcium concentrations on incidence of bitter pit after cold storage for the experiments conducted at Lyndonville in 2001(A) and Milton in 2000 (B) and 2001 (C). Regression equations show predicted incidence of bitter pit (BP) based on concentrations of calcium $(\mathrm{Ca})$, expressed as $\mathrm{ppm}\left(\mathrm{mg} \cdot \mathrm{kg}^{-1}\right)$ in fruit tissue.

applied. Then fruit were then stored at $37^{\circ} \mathrm{F}\left(2.8{ }^{\circ} \mathrm{C}\right)$ to avoid chilling injury (soft scald) that would have interfered with bitter pit evaluations. Delayed cooling and warmer storage temperatures both favor development of bitter pit in 'Honeycrisp' apples (Watkins et al., 2004).

$\mathrm{CaCl}_{2}$ provided better control of bitter pit than any of the other materials evaluated in this study. In the Milton orchard, control was better in 2001 than in 2000 when less $\mathrm{CaCl}_{2}$ was applied [3.2 vs. $1.2 \mathrm{lb} /$ acre (3.59 vs. 1.35 $\left.\left.\mathrm{kg} \cdot \mathrm{ha}^{-1}\right)\right]$ actual calcium for 2001 and 2000 , respectively). Also, $\mathrm{CaCl}_{2}$ was applied six times in 2001 compared with only four times in 2000 , and the applications at Milton were initiated during May in 2001 compared with July in 2000. The total amount of elemental calcium that was applied at Milton and Gardiner in 2000 was too low to control bitter pit on young trees of a bitter-pit susceptible cultivar such as 'Honeycrisp.' Based on results from Lyndonville (Table 2), it appears that a seasonal total of at least $2.9 \mathrm{lb} /$ acre of elemental calcium is required to suppress bitter pit on young 'Honeycrisp' trees with a canopy size that requires $100 \mathrm{gal} /$ acre of spray for complete dilute spray coverage. In the Lyndonville trial, the maximum labeled rate was used for most of the calcium formulations tested, and a total of six applications were made. When product labels allow for applications of only small amounts of elemental calcium in each spray, application of $2.9 \mathrm{lb} /$ acre of elemental calcium per season can be accomplished only by making more than six applications. Label limitations on rates per acre become even more problematic in orchards with larger trees that would require more than $100 \mathrm{gal} / \mathrm{acre}$ of dilute spray to achieve the same coverage tested in these experiments.

The $\mathrm{CaCl}_{2}$ effect on crop load in this experiment made it impossible to determine how much of the $\mathrm{CaCl}_{2}$-induced reduction in bitter pit observed in the Milton 2001 trial is attributable to increased uptake of calcium by the fruit and how much is attributable to reduced bitter pit susceptibility normally associated with smaller fruit. However, activity of $\mathrm{CaCl}_{2}$ was not enhanced by combining $\mathrm{CaCl}_{2}$ with trifloxystrobin, sodium borate, or harpin protein. Multiple applications of sodium borate in Milton in 2001 resulted in earlier ripening but did not enhance the control of bitter pit.

The finding that trifloxystrobin treatment reduced bitter pit at harvest at Milton in 2000 is consistent with data provided by Novartis researchers for experiments they conducted in 1998 and 1999 (M.A. Pastor-Corrales, personal communication). However, differences between trifloxystrobin-treated fruit and control fruit were significant in only one of the four trials reported here. In the trial where trifloxystrobin treatment significantly reduced the incidence of bitter pit at harvest, the effect of the trifloxystrobin treatment disappeared when fruit were re-evaluated after cold storage. The severity of the trial conditions may have decreased the likelihood of detecting bitter pit suppression from trifloxystrobin, sodium borate, and harpin protein, especially if those products are only weakly suppressive. Nevertheless, results clearly show that $\mathrm{CaCl}_{2}$ will provide better control of bitter pit than any of the other materials and that activity of 
$\mathrm{CaCl}_{2}$ cannot be enhanced by adding the other products tested.

As a result of this research, 'Honeycrisp' producers will be advised to make at least six applications of $\mathrm{CaCl}_{2}$ per season with the objective of applying a seasonal total of at least $3 \mathrm{lb} / \mathrm{acre}$ $\left(3.4 \mathrm{~kg} \cdot \mathrm{ha}^{-1}\right)$ of elemental calcium on 'Honeycrisp' trees that can be sprayed to drip with $100 \mathrm{gal} / \mathrm{acre}$ of spray solution. Rates of calcium may need to be increased proportionately for larger trees with canopies that require more than $100 \mathrm{gal} /$ acre for complete coverage with a dilute spray.

\section{Literature cited}

Bartlett, D.W., J.M. Clough, J.R. Godwin, A.A. Hall, M. Hamer, and B. Parr-Dobrzanski. 2002. The strobilurin fungicides. Pest Mgt. Sci. 58:649-662.

Blanpied, G.D. and K.J. Silsby. 1992. Predicting harvest date windows for apples. Cornell Coop. Ext. Info. Bul. 221.

Dong, H., T.P. Delaney, D.W. Bauer, and S.V. Beer. 1999. Harpin induces disease resistance in Arabidopsis through the systemic acquired resistance pathway mediated by salicylic acid and the NIMI gene. Plant J. 20:207-215.

Faust, M. and C.B. Shear. 1968. Corking disorders of apples: A physiological and biochemical review. Bot. Rev. 34:441-469.

Ferguson, I.B. and C.B. Watkins. 1989. Bitter pit in apple fruit. Hort. Rev. 11:289-355.

Greweling, T. 1976. Chemical analysis of plant tissue. Cornell Univ. Agr. Expt. Sta. Res. Bul. 6(8). Ithaca, N.Y.
Luby, J.J. and D.S. Bedford. 1992. Honeycrisp apple. Univ. Minn. Agr. Expt. Sta. Rpt. 225-1992 (AD-MR-5877-B).

Rosenberger, D., J. Schupp, C. Watkins, K. Iungerman, S. Hoying, D. Straub, and L. Cheng. 2001. Honeycrisp: Promising profit maker or just another problem child? N.Y. Fruit Quarterly 9(3):9-13.

Tong, C., D. Krueger, Z. Vickers, D. Bedford, J. Luby, A. El-Shiekh, K. Shackel, and H. Ahmadi. 1999. Comparison of softening-related changes during storage of 'Honeycrisp' apple, its parents, and 'Delicious'. J. Amer. Soc. Hort. Sci. 124:407-417.

Turner, N.A., I.B. Ferguson, and R.O. Sharples. 1977. Sampling and analysis for determining the relationship of calcium concentration to bitter pit in apple fruit. N.Z. J. Agr. Res. 20:525-532.

Watkins, C. 1997. Update on calcium and DPA research. Proc. Apple Harvesting, Handling, and Storage Wkshp. NRAES. Ithaca, N.Y. 112: 65-73.

Watkins, C.B., J.F. Nock, S.A. Weis, S. Jayanty, and R.M. Beaudry. 2004. Storage temperature, diphenylamine, and pre-storage delay effects on soft scald, soggy breakdown and bitter pit of 'Honeycrisp' apples. Postharvest Biol. Technol. 32:213-221.

Ypema, H.L. and R.E. Gold. 1999. Kresoxim-methyl: Modification of a naturally occurring compound to produce a new fungicide. Plant Dis. 83: 4-19. 